УДК 343.98

DOI https://doi.org/10.32837/pyuv.v0i3(32).611

\author{
В. М. Плетенець \\ orcid.org/0000-0002-3619-8624 \\ кандидат юридичних наук, доцент, \\ доцент кафедри криміналістики, судової медицини та психіатрії \\ Дніпропетровського державного університету внутрішніх справ
}

\title{
СТИЛЬ КЕРІВНИЦТВА ЯК ФАКТОР УПРАВЛІНСЬКОЇ ДІЯЛЬНОСТІ КЕРІВНИКА СЛІДЧО-ОПЕРАТИВНОЇ ГРУПИ В ПОДОЛАННІ ПРОТИДІЇ РОЗСЛІДУВАННЮ
}

Постановка проблеми. Успіх як результат розслідування кримінального провадження залежить від якості організації цієї діяльності. За умов застосування злочинцями сучасних засобів вчинення та маскування кримінальних правопорушень перед правоохоронцями постає завдання пошуку можливостей якісного розслідування та подолання проявів протидії зазначеній діяльності з боку зацікавлених осіб. Сприяти цьому може спільне виконання діяльності співробітників різних підрозділів у рамках слідчо-оперативної групи.

Дослідженню проблем використання слідчо-оперативних груп були присвячені роботи: Т.В. Авер'янової, Ю.П. Аленіна, К.В. Антонова, О.М. Бандурки, В.П. Бахіна, Р.С. Бєлкіна, В.Д. Берназа, В.В. Бірюкова, Т.В. Варфоломеївої, О.М. Васильєва, А.Ф. Волобуєва, В.І. Галагана, В.Г. Гончаренка, В.А. Журавля, А.В. Іщенка, Н.С. Карпова, В.С. Кузьмічова, Н.І. Клименко, О.Н. Колесниченка, В.О. Коновалової, В.П. Колмакова, М.В. Корнієнка, В.В. Лисенка, Л.М. Лобойка, В.К. Лисиченка, В.Г. Лукашевича, Є.Д. Лук'янчикова, Г.А. Матусовського В.А. Мисливого, П.Я. Мінки, В.Т. Нора, О.В. Одерія, М.В. Салтевського, М.Я. Сегая, О.П. Снігерьова, В.В. Тищенка, В.М. Тертишника, Л.Д. Удалової, П.В. Цимбала, К.О. Чаплинського, Ю.М. Чорноус, В.Ю. Шепітька, М.Є. Шумила, М.П. Яблокова та ін.

Водночас питанням стилів керівництва слідчо-оперативними групами при розслідуванні та подоланні проявів протидії цій діяльності з боку зацікавлених осіб належної уваги науковцями приділено не було. Це зумовлюе труднощі, з якими мають справу правоохоронці в організації своєї діяльності за умов проявів протидії розслідуванню. Дослідження стилів керівництва в діяльності слідчо-оперативних груп зумовлюється практичними потребами, що не завжди враховується в організації цього виду взаємодії. Як наслідок, знижується його ефективність і не досягаються результати, на які розрахована та спроможна спільна діяльність правоохоронців у рамках досліджуваної форми взаємодії.
Метою статті є висвітлення впливу стилю керівництва на діяльність слідчо-оперативної групи у подоланні проявів протидії розслідуванню.

Виклад основного матеріалу дослідження. Тлумачний словник визначає стиль як сукупність зовнішніх ознак, особливостей, властивих чому-небудь, кому-небудь, характерних рис якої-небудь поведінки, діяльності, методу роботи $[1$, c. 424$]$.

У свою чергу, стиль керівництва визначається як особливості взаємодії керівника з колективом, що виникають стабільно та формуються під впливом об'єктивних і суб'єктивних умов управління, таких як індивідуально-психологічні особливості особистості керівника [2, с. 399].

На особливу форму взаємодії співробітників різних підрозділів у ході розслідування й розрахована слідчо-оперативна група. Так, слідчооперативна група, як наголошує В.Г. Кучкіна, $е$ унікальною формою взаємодії слідчих і співробітників оперативних підрозділів, створюваною для розкриття і розслідування злочинів особливої важливості, яка передбачає «наявність індивідуальних і спрощених правил спільної діяльності iї членів» [3, с. 129]. Таким чином, під стилем керівництва варто розуміти систему поведінки слідчого, організацію його власної діяльності та діяльності співробітників, котрі входять до складу слідчо-оперативної групи, а також сукупність застосовуваних ним методів і прийомів.

Науковці, що здійснювали свої дослідження в галузі управління, виділяють три стилі керівництва: 1) авторитарний; 2) демократичний; 3) ліберальний [4-6]. 3 урахуванням зазначених стилів спробуємо розглянути можливості їх застосування в управлінській діяльності керівника слідчооперативної групи взагалі та для подолання проявів протидії розслідуванню зокрема.

Автократичний (авторитарний) стиль може бути охарактеризований із позиції централізації влади в одних руках, коли до складу групи входять співробітники з менш сильними темпераментом і характером, ніж у слідчого, який, окрім керівника, виступатиме ще й лідером.

Застосування авторитарного стилю, на думку О.А. Цируль, виправдане в таких випадках: у 
кризовій ситуації, коли рішення повинні прийматися швидко і бути чітко скоординованими; якщо завдання великою мірою орієнтоване на результат; коли працівник неохоче береться за виконання роботи; коли цілі не досягнуті; в період становлення, тобто на початковому етапі формування організації, її трудового колективу, коли у працівників не сформовані навички бачення цілей i шляхів їх досягнення [7].

Коли стоїть питання лише отримання результату, засобам надається другорядне значення. Це передбачає широке використання тиску, вольового спонукання, пов'язаного із грубістю і чванством, явним нехтуванням думками та пропозиціями підлеглих [8, с. 82]. Здебільшого «генератором» ідей виступатиме слідчий, що призводить до односторонності інформації та діяльності слідчооперативної групи. Звіт про виконані вказівки передбачає відповідну форму, зазвичай письмового рапорту, без супроводження коментарем отриманої інформації. Таким чином, може бути упущена вагома обставина, а слідство - піти хибним шляхом. У групі формується несприятливий морально-психологічний клімат не тільки з позиції назрівання конфліктів і взаємної недовіри, а й виконання поставлених перед співробітниками завдань. Однак до якогось моменту група може характеризуватися виконавською дисципліною, що сприяє стабілізації складної ситуації. Подолання окремих проявів протидії розслідуванню здійснюється швидко, однак не системно, без заглиблення у зміст проблеми та вирішення ситуації по суті.

Демократичний стиль керування може бути охарактеризовано високим рівнем децентралізації управління й активною участю у прийнятті рішень всіх членів групи за відсутності явного лідера. Приблизно з однаковими показниками темпераменту, характеру, досвіду група, на нашу думку, буде характеризуватися продуктивністю в усвідомленні задач і шляхів їх вирішення. Рівень згуртованості такої групи високий, що зумовлено професіоналізмом і ставленням до здійснення індивідуального внеску у виконання спільного завдання.

Демократичний стиль передбачає гнучке поєднання у процесі управління факторів і механізмів формальної та неформальної структур життєдіяльності колективу [8, с. 83]. Тобто взаємини доцільно будувати на основі таких високих якостей, як: організованість компетентність, діловитість, вимогливість, моральність тощо.

Спільне обговорення породжує взаємну довіpy i створює у групі сприятливий, вільний морально-психологічний клімат. Незважаючи на принциповість і низький рівень конформності співробітників, це сприятиме пошуку оптимальних виважених і грунтовних рішень. Звіт про виконання завдань, здійснений усно, допускає емоційне забарвлення, тобто власні припущення, внутрішне переконання співробітників, насамперед коли вони суперечать вже отриманим даним. У такий спосіб втрата вагомої інформації зводиться до мінімуму, а факти протидії розслідуванню виявляються вже за першими їхніми проявами.

Негативними моментами демократичного стилю, на думку Т.Б. Гриценко, є те, що: не здійснюється суворого централізованого контролю; відповідальність за виконання може довго перекладатися; затягується процес ухвалення рішень i їхне виконання; на обговорення проблеми витрачається значно більше часу; робота колективу буде успішною, лише якщо начальник володіє незвичайним талантом говорити з людьми та переконувати їх [9]. Це визначається недостатньою оперативністю, мобільністю, динамічністю, що певним чином може ускладнювати процес подолання протидії розслідуванню.

Ліберальний (поблажлиивий) стиль керівництва можливий за умови відданості справі, ініціативності та високої свідомості всіх членів групи. Мінімальне втручання у виконання кожним учасником групи вимагає від керівника управлінської майстерності, такту, високої ерудиції, поінформованості про дії учасників. Однак керівник може характеризуватися й недостатністю управлінського рівня, що впливатиме на формування свідомості членів групи. Відповідно, вказівки та доручення слідчого будуть виконуватися формально, незважаючи на те, що співробітники можуть мати високий фах i значний досвід діяльності, у т. ч. за умов протидії розслідуванню. Він грунтуватиметься на тому, що учасники не відчуватимуть об'єднуючого їх фактору, суб’єкта, яким у цьому випадку слідчий не $є$, а також не усвідомлюють значення індивідуальних зусиль в отриманні командного результату. Такий стиль зазвичай притаманний для слідчих, котрі не впевнені та недостатньо компетентні, мають незначний термін практичної діяльності та знань.

Наша думка підтверджується i позицією П.В. Мельник, яка наголошує, що застосування ліберального стилю виправдане, якщо це творчий колектив, де співробітники відрізняються самостійністю і творчою індивідуальністю; якщо персонал виконує індивідуальну роботу й укомплектований висококваліфікованими працівниками із виправдано високими амбіціями; за високої кваліфікації працівників і низького рівня підготовки керівника [10].

Таким чином, стиль керівництва зумовлює прийняття рішень, що впливає на отримуваний результат, за яким і оцінюється діяльність групи. Відповідно, робота слідчо-оперативної групи вимагає чіткої організації, постійного планування діяльності загалом і кожного члена СОГ зокрема, визначення обсягу і напрямів взаємного інформування учасників [11, с. 3-4]. 
Заслуговує на увагу і те, що слідчо-оперативна група - це лише форма взаємодії співробітників, котрі мають спільні задачі на конкретному етапі розслідування. У слідчого немає достатньої влади над співробітниками групи, члени якої не є його підлеглими. Таким чином, слідчому для отримання позитивного результату від взаємодії необхідно орієнтуватися на підтримку особистих відносин.

Проведене нами анкетування слідчих з'ясувало, що між практичним досвідом і застосовуваним стилем керівництва слідчо-оперативної групою існує зв'язок. Так, співробітники слідчих підрозділів із досвідом діяльності:

- до 3 років - використовують ліберальний $(69 \%)$, демократичний $(21 \%)$, авторитарний $(10 \%)$ стилі керівництва;

- від 3 до 10 - авторитарний (45\%), демократичний $(41 \%)$ ліберальний $(14 \%)$;

- понад 10 років - віддають перевагу демократичному $(71 \%)$, авторитарному $(22 \%)$, ліберальному $(7 \%)$.

Отримані результати мають логічне пояснення. Так, на початку своєї діяльності слідчий (до 3 років) відчуває істотні труднощі, що зумовлено недостатнім рівнем знань, досвіду професійного, життєвого. Кількість проваджень, за якими б формувалися слідчо-оперативні групи, є незначною, що і пояснюється використанням здебільшого ліберального стилю керування.

Надалі слідчі (від 3 до 10 років) переходять до авторитарного та демократичного стилю керівництва, що приблизно однаковою мірою обираються ними.

За наявності значного досвіду роботи (понад 10 років) слідчі віддають перевагу демократичному стилю керівництва слідчо-оперативною групою. На обрання цього стилю впливає як досвід організації діяльності розглядуваної форми взаємодії, так і подолання проявів протидії розслідуванню.

Не меншого значення на формування відповідного стилю керівництва групою мають і комунікативні якості. Це сприяє мінімізації бар'єрів у спілкуванні та формуванню доброзичливої обстановки у слідчо-оперативній групі.

Вагоме значення в обранні стилю керування має й авторитет слідчого серед колег. Його вплив, якщо порівняти між собою співробітників із досвідом до трьох і понад десять років, однозначно працюватиме на користь останніх. Таким чином, зазначені дані демонструють динамічний процес, вдосконалення слідчими вмінь і навичок керівництва слідчо-оперативними групами взагалі та за умов протидії розслідуванню з боку зацікавлених осіб зокрема. Водночас стилі керівництва не зводяться лише до зазначених нами трьох, котрі рідко існують у чистому вигляді. Зазвичай простежується їхнє поєднання з домінуванням одно- го 3 них, що зумовлюється умовами та ситуацією протидії розслідуванню, особливостями членів групи. Тому керівникові необхідно «відчувати» ïx, враховувати це як специфіку діяльності та, відповідно, визначати стиль, який не має бути чимось статичним. Навпаки, динамічність у поєднанні різних стилів керівництва може бути запорукою ефективної діяльності слідчо-оперативної групи.

Висновки. Найвищих результатів досягають ті керівники, котрі сформували оптимальний стиль діяльності, зумовлений конкретними обставинами розслідування.

Стиль керування слідчого та поведінка щодо учасників слідчо-оперативної групи має змінюватися залежно від умов, що складаються на відповідний момент розслідування та подолання проявів протидії цій діяльності з боку зацікавлених осіб. Вміло обрані та гнучко, творчо застосовані стилі керівництва є головним індикатором діяльності слідчо-оперативної групи за умов протидії розслідуванню. Висока ефективність використання розглядуваної форми організації взаємодії характеризуватиметься мінімальними затратами часу, сил і засобів на досягнення тих цілей, задля яких вона формувалася.

Подальші наші дослідження спрямовуватимуться на можливості використання спеціальних знань у подоланні протидії розслідуванню.

\section{Jimepamypa}

1. Персонал : словарь понятий и определений / П.В. Журавлев, С.А. Карташев, Н.К. Маусов, Ю.Г. Одегов. Москва : Экзамен, 2000. 511 с.

2. Государственное и муниципальное управление : справочник. Москва : Магистр, 1997. 497 с.

3. Кучкина В.Г. Участие сотрудников оперативных подразделений в следственно-оперативных группах: теоретические и практические аспекты. Юридическая наука и практика. Вестник Нижегородской академии МВД России. 2012. № 19. С. 129.

4. Атаманчук Г.В. Теория государственного управления : курс лекций. Москва : Юрид.лит., 1997. 400 с.

5. Омаров А.М. Руководитель: размышления о стиле управления. Момсква : Политиздат, 1987. 366 с.

6. Чернобровка И. основные стили руководства. Бизнес-информ. № 12. 1997. С. 50-53.

7. Цуруль О.А. Менеджмент у державних організаціях : навчальний посібник. Київ : КНЕУ, 2002. 142 с.

8. Виноградський М.Д., Шканова О.М. Організація праці менеджера : навчальний посібник. Київ : Кондор, 2002.518 с.

9. Гриценко Т.Б., Іщенко Т.Д., Мельничук Т.Ф. Етика ділового спілкування : навчальний посібник. Київ : Центр навчальної літератури, 2007. 344 с.

10. Менеджмент : навчальний посібник / П.В. Мельник, М.М. Філоненко, Л.П. Гацька, Н.Е. Кошарська. Ірпінь : Академія ДПС України, 2001. 154 с.

11. Багмет А.М. Планирование как одна из форм не процессуального взаимодействия следователей с органами дознания при раскрытии и расследовании массовых беспорядков. Российский следователь. 2012. № 6 . C. $3-4$. 


\section{Анотація}

Плетенець В. М. Стиль керівництва як фактор управлінської діяльності керівника слідчо-оперативної групи в подоланні протидії розслідуванню. - Стаття.

Стаття присвячена розгляду стилів керівництва слідчо-оперативною групою у подоланні проявів протидії розслідуванню. На підставі аналізу здійснених у галузі управління та криміналістики досліджень визначаються можливості стилів керівництва слідчо-оперативною групою як форми взаємодії співробітників. Наголошується, що недостатня увага до вивчення стилів керівництва в діяльності слідчо-оперативних груп призводить до зниження їх ефективності. Також стає неможливим отримання результатів, на які розрахована та спроможна спільна діяльність правоохоронців у рамках досліджуваної форми взаємодії.

Такі стилі керівництва, як авторитарний, демократичний і ліберальний розглядаються з позиції значення для процесу збору інформації, її оцінки, впливу на учасників і прийняття відповідних рішень.

У статті наводяться результати анкетування слідчих із поділом на категорії залежно від досвіду практичної діяльності та визначено у відсотковому відношенні використання ними певного стилю (авторитарного, демократичного та ліберального).

На підставі проведеного дослідження наголошується на зв'язку між застосуванням стилю керівництва та досвідом, комунікабельністю слідчого та його авторитетом серед колег. Акцентується увага на необхідності комбінування декількох стилів, один із яких може виступати домінуючим. Це зумовлено проявами протидії розслідуванню, особливостями співробітників, які входять до складу групи, та завдань, що перед нею постають. Наголошується, що стиль керівництва має характеризуватися гнучкістю у застосуванні методів роботи в розглядуваній групі та зумовлюватися прийняттям рішень, які впливають на отримуваний результат у подоланні протидії розслідуванню.

У висновках зазначається, що висока ефективність використання розглядуваної форми організації взаємодії характеризуватиметься мінімальними затратами часу, сил і засобів на досягнення тих цілей, задля яких вона формувалася.

Ключові слова: стиль керівництва, слідчий, взаємодія, протидія розслідуванню.

\section{Summary}

Pletenets V. M. Management style as a factor of management activity of operational group head in overcoming counteraction to investigation. - Article.

The article is devoted to consideration of styles of management of the investigative and operational group in overcoming manifestations of counteraction to investigation. Based on the analysis carried out in the branch of management and criminalistics, the research determines the possibilities of the leadership styles of the investigative and operational group as a form of interaction of employees. It is noted that insufficient attention to the study of leadership styles in the activities of investigative and operational groups leads to a decrease in their effectiveness. It is also not impossible to obtain results for which joint activities of law enforcement officers are designed and possible.

Leadership styles such as: authoritarian, democratic and liberal are considered from a value position for the process of collecting their evaluation information, influence and decision-making.

The article gives the results of the questionnaire of investigators with a division into categories, depending on the experience of practical activities, and determines, in percentage terms, the use of (authoritarian, democratic and liberal) styles by them. Based on the research carried out, it is noted on the connection between the application of the style of leadership and experience, communicability.

Emphasis is placed on the need to combine several styles, one of which can act as dominant. This is due to the conditions and manifestations of opposition to investigation, the characteristics of employees who are part of the group and tasks that appear before it.

It is noted that the style of leadership should be characterized by flexibility in the application of working methods in the group under consideration and should be conditioned by decision-making, which affect the result obtained in overcoming the manifestations of opposition to investigation.

The conclusions indicate that the high effectiveness of the interaction arrangement under consideration will be characterized by the minimum time, effort and means to achieve the goals for which it was formed.

Key words: leadership style, investigator, interaction, counteraction of investigation. 